\title{
Larangan pemberian dot/kempeng dan makanan/minuman selain asi dengan cakupan asi eksklusif di kabupaten pangkep
}

\author{
Nasriani \\ Fakultas Kedokteran Dan Ilmu Kesehatan Universitas Muhammadiyah Makassar
}

\section{Keywords :}

Exclusive ASI, Prohibition of Giving

Pacifiers / Camper, Prohibition of

Giving Food And Beverage Other Than ASI

\section{Kontak :}

Nasriani

Email : nasriani@unismuh.ac.id

Fakultas Kedokteran Dan Ilmu

Kesehatan Universitas Muhammadiyah

Makassar

DOI : https://doi.org/10.15294/

kemas.v14i3.1562

C2020J-Healt

ini adalah artikel dengan akses terbuka

dibawah licenci CC BY-NC-4.0

https://creativecommons.org/licenses/by-nc/4.0/

\begin{abstract}
In connection with the Sustainable Development Goals (SDGs), breastfeeding is one of the first steps for a human being to get a healthy and prosperous life. Unfortunately, not everyone knows this. The Indonesian government has made efforts to increase exclusive breastfeeding in various ways. The issuance of laws and regulations regarding exclusive breastfeeding has also been carried out, but the implementation has not been in accordance with the Indonesian National Standard (SNI). The low coverage of exclusive breastfeeding can have an impact on the quality of life of the nation's next generation and also on the national economy. This study aims to analyze the relationship between the prohibition of pacifiers / pacifiers and the prohibition of food / drink other than breast milk with exclusive breastfeeding coverage in Pangkep Regency. This study was an observational analytic study with a cross sectional study design. The population in this study was the head of the puskesmas / program responsible and post partum mothers who were in all Pangkep District health centers, as many as 23 puskesmas. Sampling from the study population was carried out by means of purposive sampling namely 22 puskesmas with inpatients in Pangkep district. Data collection was carried out by looking at the exclusive ASI report of the Pangkep District Health Office, distribution of questionnaires, interviews and then processed using the SPSS program with the chi square test. Data analysis techniques using univariate, bivariate and multivariate tests with the forward step method (conditional). Results showed that $p=$ 1,000 ( $p>0.05$ ) which means that HO was accepted. Thus there is no relationship between the prohibition of giving pacifiers / pacifiers and the prohibition of giving food / drink other than breast milk related to exclusive breastfeeding coverage. Recommendation, Provision of information and education to nursing mothers about the importance of breastfeeding and the negative impact of using pacifiers.
\end{abstract}




\section{PENDAHULUAN}

Ditinjau dari segala aspek, pemberian air susu ibu (ASI) sangat bermanfaat bagi tumbuh kembang bayi. Menurunnya prevalensi dan durasi menyusu, terbukti menaikkan angka morbiditas dan mortalitas bayi, baik di negara-negara berkembang maupun di negara-negara yang maju. Kebijakan Nasional untuk memberikan ASI eksklusif selama 6 (enam) bulan telah ditetapkan dalam SK Menteri

Kesehatan No.450/Menkes/SK/IV/2004. Cakupan pemberian ASI eksklusif secara nasional belum memenuhi target nasional, salah satunya karena adanya stigma dan stereotipe bahwa menyusui merupakan urusan perempuan.

Pola pemberian makan terbaik untuk Bayi sejak lahir sampai anak berumur 2 (dua) tahun meliputi: (a) memberikan ASI kepada Bayi segera dalam waktu 1 (satu) jam setelah lahir; (b) memberikan hanya ASI saja sejak lahir sampai umur 6 (enam) bulan. Hampir semua ibu dapat dengan sukses menyusui diukur dari permulaan pemberian ASI dalam jam pertama kehidupan Bayi. Menyusui menurunkan risiko infeksi akut seperti diare, pnemonia, infeksi telinga, haemophilus influenza, meningitis dan infeksi saluran kemih. Menyusui juga melindungi Bayi dari penyakit kronis masa depan seperti diabetes tipe 1. Menyusui selama masa Bayi berhubungan dengan penurunan tekanan darah dan kolesterol serum total, berhubungan dengan prevalensi diabetes tipe 2 yang lebih rendah, serta kelebihan berat badan dan obesitas pada masa remaja dan dewasa.

WHO dan UNICEF telah mencanangkan 10 Langkah Menuju Keberhasilan Menyusui dan diimplementasikan pada Deklarasi Inosenti 1990, yang merupakan dasar dari Program Rumah Sakit Sayang Bayi, dengan tujuan meningkatkan pemberian ASI kepada seluruh bayi. Dan dalam rangka memperingati 20 tahun Deklarasi Inosenti tersebut, pengimplementasian 10 Langkah Menuju Keberhasilan Menyusui menjadi tema dalam rangkaian acara peringatan Pekan Asi Sedunia 1 - 7 Agustus 2010.
ASI Eksklusif sendiri didefinisikan sebagai ASI yang diberikan kepada bayi sejak dilahirkan selama 6 (enam) bulan, tanpa menambahkan dan/atau mengganti dengan makanan atau minuman lain. Demikian tertuang dalam Pasal 1 angka 1 Peraturan Menteri Kesehatan Nomor 15 Tahun 2014 tentang Tata Cara Pengenaan Sanksi Administratif bagi Tenaga Kesehatan, Penyelenggara Fasilitas Pelayanan Kesehatan, Penyelenggara Satuan Pendidikan Kesehatan, Pengurus Organisasi Profesi di Bidang Kesehatan, serta Produsen dan Distributor Susu Formula Bayi dan/atau Produk Bayi Lainnya yang Dapat Menghambat Keberhasilan Program Pemberian Air Susu Ibu Eksklusif.

Pada tubuh bayi, usus adalah organ yang bertugas menyeleksi makanan mana yang dapat membahayakan kesehatannya. Untuk mencegah masuknya bahan-bahan alergen ke dalam aliran darah, usus yang sudah 'cukup dewasa' mengeluarkan $\lg \mathrm{A}$, yaitu protein immunoglobulinyang berfungsi seperti lapisan pelindung pada dinding usus.

Bayi di bawah 6 bulan $\lg$ A-nya belum cukup banyak, sehingga walaupun $\lg \mathrm{A}$ juga terdapat pada ASI, bahan alergen lebih mudah masuk ke dalam aliran darah. Itulah sebabnya kita tidak disarankan memberi makanan bayi sebelum usianya mencapai 6 bulan. Alergi adalah salah satu bahayanya bila kita memberi mereka MPASI terlalu dini.

Langkah Ke sembilan dari sepuluh langkah tersebut menyebutkan : Tidak memberikan dot atau kempeng kepada bayi, langkah ini dimaksudkan bahwa semua bayi yang menetek akan selalu mendapatkan ASI, dan tidak akan terganggu proses menyusunya dengan penggunaan dot atau kempeng.

Dot juga dikenal sebagai dummy, sootheratau pacifier, adalah pengganti puting susu (ibu) yang biasanya terbuat dari karet atau plastik. Penggunaan dot dianggap bermanfaat, karena akan menenangkan bayi serta memberikan rasa nyaman pada keadaankeadaan tertentu seperti keinginan untuk mulai tidur, rasa nyeri pada waktu gigi tumbuh, dipisahkan dari ibunya, menurunkan 
frekuensi menghisap jari, serta menurunnya kejadian SIDS (sudden infant death syndrome).

Farahdibha Tenrilemba yang merupakan sekretaris Jenderal Asosiasi Ibu Menyusui Indonesia (AIMI), menjelaskan bahwa Dot memberikan pemenuhan rasa puas yang salah pada bayi karena puting tiruan tidak sama dengan puting asli. Inilah mengapa pemakaian dot akan mengganggu proses menyusu ke payudara yang menyebabkan bayi mudah mengalami bingung puting. Pemakaian dot juga akan memperpendek durasi pemberian ASI sehingga menghambat tercapainya ASI ekslusif selama 6 bulan dan keberlanjutan pemberian ASI hingga 2 tahun atau lebih. Semakin sering pemakaian dot, semakin kurang produksi ASI.

Puskesmas (Pusat Kesehatan Masyarakat) adalah suatu organisasi kesehatan fungsional yang merupakan pusat pengembangan kesehatan masyarakat yang juga membina peran serta masyarakat di samping memberikan pelayanan secara menyeluruh dan terpadu kepada masyarakat di wilayah kerjanya dalam bentuk kegiatan pokok, salah satunya adalah pelayanan persalinan. Adapun data persalinan di seluruh puskesmas Kabupaten Pangkep tahun 2015 sebanyak $5.462(82,09 \%)$ ibu sedangkan yang bersalin di RSUD Pangkep sebanyak 1.192 (17,91\%) ibu. (Dinkes Kabupaten Pangkep, 2016).

Persentase cakupan ASI eksklusif pada bayi 0-6 bulan di wilayah Puskesmas kabupaten pangkep yakni pada tahun 2011 sebesar $41.28 \%$, tahun 2012 mengalami peningkatan sebesar $57.79 \%$, tahun 2013 juga mengalami peningkatan menjadi $(68,10 \%)$ dan mengalami penurunan pada tahun 2014 sebesar $64,4 \%$ dan meningkat kembali pada tahun 2015 menjadi 67,71\%. Meskipun cakupan ASI eksklusif di wilayah kerja puskesmas ini telah mengalami peningkatan, namun cakupan ASI eksklusif tersebut masih di bawah standar nasional sebesar $80 \%$.

ASI sangat penting bagi bayi namun tidak semua ibu memberikan ASI eksklusif. Pemerintah mencanangkan beberapa program terkait ASI eksklusif, namun hal tersebut belum berhasil karena cakupan ASI Eksklusif belum sesuai standar nasional Indonesia (SNI) yakni $\geq 80 \%$. Maka perlu dilakukan penelitian yang bertujuan untuk mengetahui hubungan larangan pemberian dot dan makanan/minuman selain ASI dengan cakupan ASI eksklusif di kabupaten pangkep.

\section{METODE}

\section{Desain Penelitian}

Penelitian ini dilakukan di seluruh

Puskesmas Kabupaten Pangkep. Penelitian ini merupakan penelitian observasional dengan desain cross sectional..

\section{Tempat dan Waktu}

Penelitian ini dilaksanakan di seluruh Puskesmas Kabupaten Pangkep pada bulan Juli sampai Agustus 2016.

\section{Sampel}

Penarikan sampel dalam penelitian ini dilakukan dengan cara purposive sampling yaitu kepala puskesmas / penanggung jawab program 10 LMKM dan ibu post partum yang berada di seluruh puskemas Kabupaten Pangkep yang memiliki rawat inap sebanyak 22 puskesmas.

\section{Prosedur Pengambilan}

Data primer dikumpulkan dengan melakukan wawancara dengan kepala puskesmas/ penanggung jawab program dan ibu post partum, sedangkan data sekunder diperoleh dari puskesmas dan dinas kesehatan Kabupaten Pangkep.

\section{Analisa data}

Analisa data dilakukan dengan uji statistik dengan menggunakan uji univariat dengan distribusi frekuensi, bivariat dengan chi square dan multivariat dengan uji regresi logistic dengan menggunakan metode forward stepwice (conditional). 


\section{HASIL}

\section{Analisis Univariat}

Grafik 1. Persentase cakupaan ASI Eksklusif di seluruh puskesmas Kabupaten Pangkep

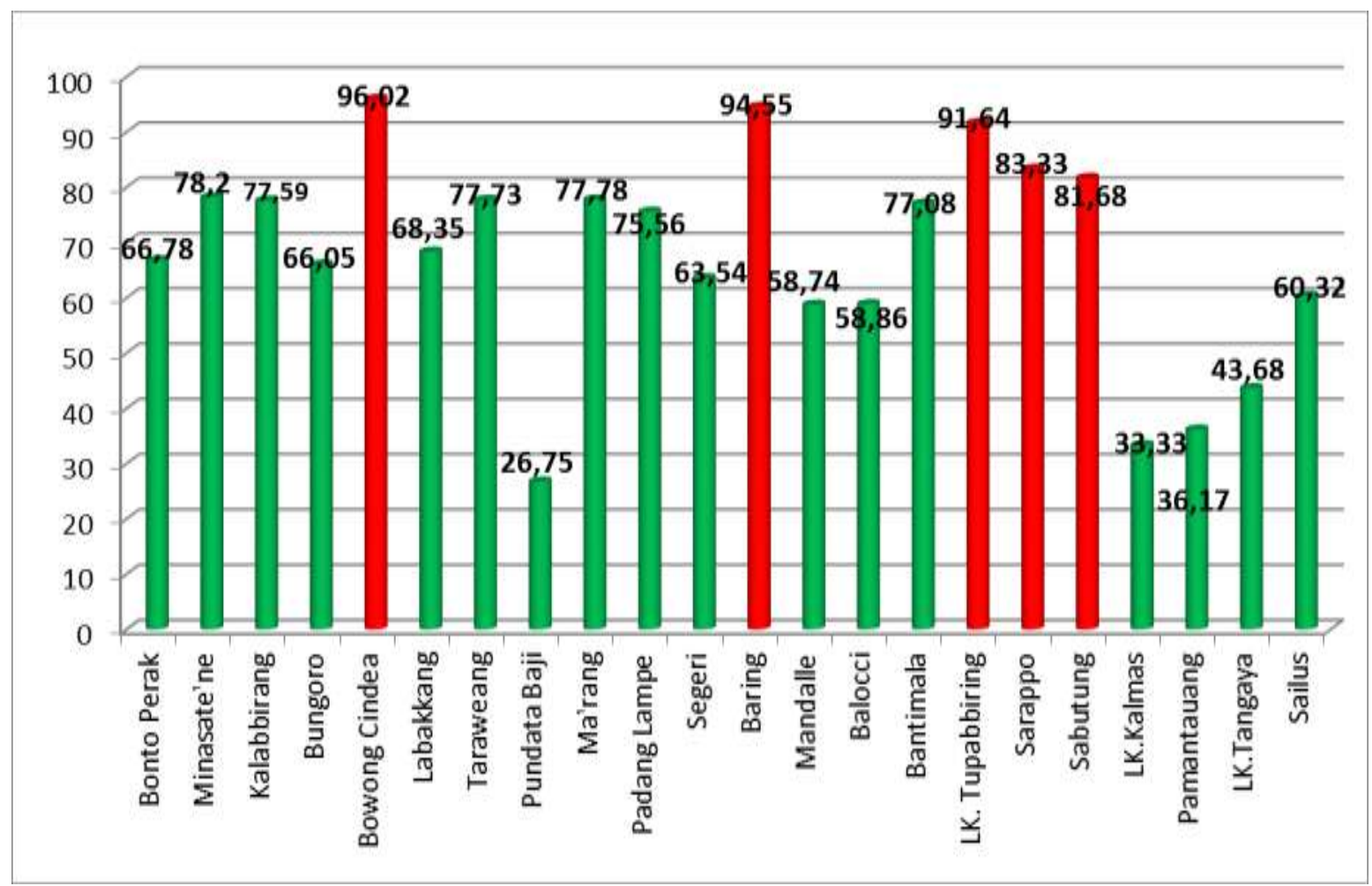

Sumber : Data Sekunder, 2015

Grafik 1 menunjukkan bahwa persentase Cakupan ASI Eksklusif masing-masing puskesmas yang memiliki rawat inap di Kabupaten Pangkep tahun 2015, yaitu : Bonto Perak (66,78\%), Minasate'ne $(78,20 \%)$, Kalabbirang $(77,59 \%)$, Bungoro $(66,05 \%)$, Kota pangkajene $(78,49 \%)$, Bowong Cinde (96,02\%), Labakkang (68,35\%), Taraweang (77,73\%), Pundata Baji (26.75\%), Ma'rang (77,78\%), Padang Lampe (75,56\%), Segeri (63,54\%), Baring (94,55\%), Mandalle (58,74\%), Balocci $(58,86 \%)$, Bantimala (77,08\%), LK. Tupabbiring (91.64\%), Sarappo (83,33\%), Sabutung (81.68\%), LK Kalmas (33,33\%), Pamantauang (36,17\%), LK Tangaya (43,68\%), Sailus (60,32\%).

Tabel 1. Distribusi frekuensi puskesmas berdasarkan Larangan pemberian dot/kempeng dan Larangan pemberian makanan/minuman selain ASI di kabupaten pangkep

\begin{tabular}{|c|c|c|}
\hline Variabel & $\mathbf{n}$ & $\%$ \\
\hline \multicolumn{3}{|l|}{ Larangan pemberian dot/kempeng } \\
\hline Ya & 20 & 90,9 \\
\hline Tidak & 2 & 9,1 \\
\hline Jumlah & 22 & 100 \\
\hline \multicolumn{3}{|c|}{ Larangan pemberian makanan/minuman selain ASI } \\
\hline $\mathrm{Ya}$ & 21 & 95,5 \\
\hline Tidak & 1 & 4,5 \\
\hline Jumlah & 22 & 100 \\
\hline
\end{tabular}

Sumber : Data Primer 2016 
Tabel 1 menunjukkan bahwa Puskesmas yang tidak melaksanakan larangan pemberian dot/kempeng sebanyak 1 Puskesmas (4,5\%), dan yang melaksanakan larangan pemberian dot/kempeng pada bayi sebanyak 21 Puskesmas (95,5\%). Sedangkan variable larangan pemberian makanan/minuman selain ASI menunjukkan bahwa Puskesmas yang tidak melaksanakan larangan pemberian makanan/minuman selain ASI sebanyak 2 Puskesmas $(9,1 \%)$, dan yang melaksanakan larangan pemberian makanan/minuman selain ASI sebanyak 20 Puskesmas $(90,9 \%)$.

\section{Analisis Bivariat}

Tabel 2. Analisis Bivariat Larangan pemberian dot/kempeng dan Larangan pemberian makanan/minuman selain ASI di kabupaten pangkep

\section{Variabel}

\section{Cakupan ASI Eksklusif Jumlah}

\begin{tabular}{|c|c|c|c|c|c|c|c|}
\hline \multirow{3}{*}{ Variabel } & \multicolumn{4}{|c|}{ Cakupan ASI Eksklusif } & \multicolumn{2}{|c|}{ Jumlah } & \multirow{2}{*}{$\mathbf{P}$} \\
\hline & \multicolumn{2}{|c|}{ Sesuai SNI } & \multicolumn{2}{|c|}{ Tidak Sesuai SNI } & & & \\
\hline & $\mathrm{n}$ & $\%$ & $\mathrm{n}$ & $\%$ & $\mathrm{n}$ & $\%$ & \\
\hline \multicolumn{8}{|c|}{ Larangan pemberian dot/ kempeng } \\
\hline $\mathbf{Y a}$ & 5 & 23,8 & 16 & 76,2 & 21 & 100,0 & \multirow[t]{2}{*}{1,000} \\
\hline Tidak & 0 & 0 & 1 & 100,0 & 1 & 100,0 & \\
\hline Jumlah & 5 & 22,7 & 17 & 77,3 & 22 & 100,0 & \\
\hline \multicolumn{7}{|c|}{$\begin{array}{l}\text { Larangan pemberian makanan/ } \\
\text { minuman selain ASI }\end{array}$} & \multirow{3}{*}{1,000} \\
\hline Ya & 5 & 23,8 & 16 & 76,2 & 21 & 100,0 & \\
\hline Tidak & 0 & 0 & 1 & 100,0 & 1 & 100,0 & \\
\hline Jumlah & 5 & 22,7 & 17 & 77,3 & 22 & 100,0 & \\
\hline
\end{tabular}

Sumber : Data Primer 2016

Tabel 2 menunjukkan variable larangan pemberian dot/kempeng dengan larangan pemberian makanan/minuman selain ASI. Larangan pemberian dot/kempeng dikategorikan menjadi dua yaitu melaksanakan dan tidak melaksanakan. Hasil penelitian diperoleh nilai $p=1,000(p>0,05)$ berarti Ho diterima. Hal ini menunjukkan bahwa tidak ada hubungan pelaksanaan tidak memberikan dot/kempeng dengan cakupan ASI Eksklusif. Variabel larangan pemberian makanan/minuman selain ASI. dikategorikan menjadi 2 yaitu melaksanakan dan tidak melaksanakan. Hasil penelitian diperoleh nilai $\mathrm{p}=1,000(\mathrm{p}>0,05)$ berarti Ho diterima. Hal ini menunjukkan bahwa tidak ada hubungan pelaksanaan larangan pemberian makanan/ minuman lain selain ASI dengan cakupan ASI Eksklusif.

\section{PEMBAHASAN}

Penelitian ini menunjukkan bahwa tidak ada hubungan antara larangan pemberian dot/kempeng tidak dengan cakupan ASI eksklusif di kabupaten pangkep.

Puskesmas yang tidak melakukan kebijakan tidak memberikan dot/kempeng pada bayi karena ibu-ibu telah memahami bahaya / kerugian penggunaan dot antara lain menyebabkan bayi memiliki ketergantungan pada kempeng (misal agar bisa tenang/tidur hams selalu memakai kempeng), bayi mengalami gangguan pada pertumbuhan gigi geligi, bayi menjadi kurang berkembang dalam kemampuan verbalnya.

Telah dijelaskan dalam Permenkes RI No.9 Tahun 2013 tentang pelarangan penggunaan produk bayi yang terkait langsung dengan kegiatan menyusui meliputi segala bentuk susu dan pangan bayi lainnya, botol susu, dot/kempeng. Dot, yang juga dikenal sebagai 
dummy, soother atau pacifier adalah pengganti puting susu ibu yang biasanya terbuat dari karet atau plastik. Penggunaan dot di fasilitas kesehatan telah dilarang karena akan menimbulkan komplikasi yang merugikan seperti terjadi gangguan pola pengisapan awal karena bayi menolak untuk menetek, meningkatnya risiko otitis media, infeksi saluran cerna dan pernapasan, serta maloklusi gigi. Penelitian yang dilakukan oleh Kurniawan (2022), menunjukkan pemakaian kempeng (pacifier) menjadi faktor yang menghalangi keberhasilan pemberian ASI Eksklusif. Di samping itu, pelarangan penggunaan dot/kempeng dimaksudkan bahwa semua bayi yang menetek akan selalu mendapatkan ASI, dan tidak akan mengganggu proses menyusuinya karena penggunaan dot/kempeng.

Upaya tenaga kesehatan untuk tidak memberikan dot/kempeng memang telah dilakukan, tapi masalah dalam menyusui memang tidak dapat dihindari. Ibu yang sering merasa produksi ASI nya sedikit, padahal ASI akan keluar lebih baik jika payudara mendapatkan rangsangan yang lebih lama dan lebih sering. Sebenarnya hampir semua ibu yang melahirkan akan berhasil menyusui bayinya dengan jumlah ASI yang cukup dan sesuai dengan kebutuhan bayinya. Hal ini harus diperhatikan agar ASI dapat diproduksi dengan jumlah dan kualitas yang baik adalah teknik menyusui yang benar, asupan gizi ibu, serta frekuensi menyusui. Selain itu bayi banyak menangis atau rewel sedangkan ibu masih butuh banyak istirahat, bayi kuning, bayi sakit, tapi produksi ASI masih sedikit sehingga menimbulkan kepanikan dan menjadikan pemberiat dot/kempeng sebagai alternatif. Keluhan dengan puting susu lecet dan terasa nyeri, ibu yang sakit sehingga tidak bisa menyusui, serta ibu bekerja yang merasa repot untuk memerah ASI nya. Hal ini lah yang menyebabkan cakupan ASI masih rendah walaupun tenaga kesehatan telah mengupayakan untuk tidak memberikan dot/kempeng pada bayi. Padahal semua masalah tersebut bisa diatasi jika ibu dibekali dengan pengetahuan tentang menyusui.
Penelitian ini juga menunjukkan menunjukkan bahwa tidak ada hubungan antara memberikan makanan/minuman selain ASI dengan cakupan ASI eksklusif di kabupaten pangkep.

Pemberian asupan makanan/minuman selain ASI pada bayi baru lahir hanya diberikan untuk kasus kegawatdaruratan medis saja. Pemberian makanan pada bayi baru lahir misalnya madu, air teh, air kelapa, air tajin, pisang, papaya dan susu formula berbahaya karena saluran pencernaan bayi belum cukup kuat untuk mencerna, selain itu dapat mengganggu produksi ASI dan mengurangi kemampuan bayi untuk mengisap. Penelitian Fikawati dan Syafiq (2009), menemukan kegagalan pemberian ASI Eksklusif dimulai sejak 3 hari pertama kelahiran karena telah diberikan makanan/minuman lain saat dilahirkan. Penelitian serupa yang dilakukan oleh Kholifah (2008), menunjukkan bahwa pemberian makanan/minuman lain selain ASI terbukti menjadi satu faktor kuat penyumbang kegagalan pemberian ASI Eksklusif pada bayi sampai 6 bulan, salah satunya bayi enggan menyusu dan menolak pemberian ASI. Waktu pertama kali bayi disusui oleh ibunya merupakan determinan penting dalam keberhasilan ASI Eksklusif, semakin lama bayi disusui maka peluang untuk bayi menerima asupan makanan/minuman lain semakin sedikit.

Beberapa fasilitas kesehatan telah menganjurkan untuk tidak memberikan makanan/minuman selain ASI kepada bayinya karena mempunyai dampak berbahaya, tapi terkadang ibu tetap memberikannya dengan berbagai alasan. Sebagian besar ibu yang tetap memberikan makanan/minuman dalam hal ini susu formula dengan alasan supaya bayi tidak menangis, yang selalu diidentikkan dengan kondisi lapar dan haus. Pengeluaran ASI yang masih sedikit pasca melahirkan menjadi alasan kuat mereka untuk memberikan susu formula kepada bayinya karena merasa cemas tidak akan membuatnya kenyang. Selain itu, memberikan madu kepada bayinya karena percaya bawa madu dapat mencegah berbagai penyakit serta memberikan kesembuhan jika 
sakit.Kebudayaan memang satu hal yang tidak dapat dipisahkan dalam kehidupan manusia. Mereka memiliki nilai-nilai untuk menetapkan pilihan dan melakukan pilihan

\section{KESIMPULAN}

Terbukti ibu yang didukung untuk menyusui, 2,5x akan lebih sukses dalam memberikas ASI. Dukungan untuk menyusui harus diberikan oleh semua pihak meliputi, pemerintah, tenaga kesehatan, masyarakat dan media. ASI eksklusif dapat meningkatkan IQ anak, potensi mendapatkan pekerjaan yang lebih baik karena memiliki fungsi kecerdasan tinggi. Tentunya hal ini akan meningkatkan potensi mendapatkan penghasilan yang lebih optimal.

Di Indonesia, hampir 14\% dari penghasilan seseorang habis digunakan untuk membeli susu formula bayi berusia kurang dari 6 bulan. Dengan ASI eksklusif, penghasilan orangtua dapat dihemat sebesar $14 \%$.

\section{UCAPAN TERIMA KASIH}

Terima kasih kami ucapkan kepada ibu Ratna Mahmud, S.Kep., Ns., M.Kes selaku Kepala Prodi Diploma III Keperawatan Fakultas Kedokteran Dan Ilmu Kesehatan Unismuh Makassar dan kepada seluruh kepala Puskesmas / penanggung jawab program 10 LMKM.

\section{DAFTAR PUSTAKA}

Astuti I. 2013. Determinan Pemberian Asi Eksklusif Pada Ibu Menyusui. Jurnal Health Quality, Vol. 4 No. 1 Hal. 1 - 76.

Dinkes Kabupaten Pangkep. (2015). Profil Kesehatan Dinas Kesehatan kabupaten Pangkep. Diakses Tanggal 10 Maret 2016. Available from : https://diskes. wordpress.com/

Ikatan Dokter Indonesia (IDAI). (2018).

Diakses Pada Tanggal 10 maret 2016.
Available

from

https://www.Kumparan.com

Imam Hadi wibowo. (2014). Larangan Bagi

Tenaga Kesehatan Memberikan Susu

Formula. Diakses Pada Tanggal 10 maret 2016. Available from https://www.hukumonline.com

Kementerian Kesehatan RI. 2010. Pedoman Pekan ASI Sedunia (PAS) 2010. Jakarta: Kementerian Kesehatan RI.

Khasanah, N. 2011. Asi Atau Susu Formula Ya?, Yogyakarta, Flashbook.

Peraturan Pemerintah Republik Indonesia. (2012). Pemberian Air Susu Ibu Eksklusif. Diakses Pada Tanggal 10 maret 2016. Available from https://jdih.kemenkeu.go.id

Riset Kesehatan Dasar (Riskesdas) 2013. Pedoman Pewawancara Petugas Pengumpul Data. Jakarta: Badan Litbangkes, Depkes RI, 2013 